\title{
空調自動制御システム機能維持における経済性評価手法に関する研究
}

\section{STUDY ON THE EVALUATION TECHNIQUE OF ECONOMIC VALUE IN MAINTENANCE OF AIR-CONDITIONING AUTOMATIC-CONTROL SYSTEM}

\author{
原 英 嗣*1, 渡邊 直 樹*2, 川井康平*3，尾島 俊 雄*4 \\ Eiji HARA, Naoki WATANABE, Kohe KAWAI \\ and Toshio OJIMA
}

\begin{abstract}
The maintenance of equipments of the buildings is important for making high-quality building as social capital up. However in the present condition, in order that economic value of the maintenance may not be evaluated, an efficiency maintenance is not performed in almost buildings, especially, the maintenace of air-conditioning automatic-cntrol system. In this thesis, the economic value in maintenance of air-conditioning automatic-control system is evaluated from the theory that the maintenance effect is equivalent to the amount of a loss due to the poor performance of economic value of comfortable air-conditioning system and the effect of the energy-saving by the automaticcontrol system. Finally, economical evaluation of maintenance of an automatic-control system is simulated.
\end{abstract}

Keywords: office building, equipment, maintenance, automatic-contorol system, evaluation technique of economic value 事務所建築、建築設備、保全、自動制御システム、経済性評価

1.はじめに

保全とは、対象設備の初期性能を維持する為の行為である。 初期性能を維持することは、一般的に長寿命につながりエネル ギ一消費量も抑えられる。しかし建築設備の保全状況調查よ り、エレベータ一、冷凍機、ボイラなど、大型設備や法定点検が 義務づけられている設備は予防保全型が多く、それ以外の設 備は、事後保全型もしくは放置型が多い1)。これは保全行為に 費用が掛かり経済性に劣ると捉えられていることが主な理由と 考える。特に対象機器が小さくなる程顕著であり、その代表的 な設備として空調自動制御システムがある。

ここで空調自動制御システムに関し、中央監視装置も含めた 累積保全費の推計を行った。調查データは、自動制御機器メ一 カーの1990年から2000年までの用途別建物 297 棟に関す る保全費馥歷である。推計方法は、稼動年数 $\mathrm{n}$ 年目における各 用途別建物の保全費 Mn 各用途別建物の延べ床面積の合 計值 Snで除した値MTnを算出する。稼動午数は、簡易的に竣 工年からの年数とする。以下に算出式を示す。

$$
S n=\sum S j 、 M n=\sum M j, M T n=\sum \frac{M j}{S j}
$$

$\mathrm{Sj}$ : 稼動年数 $\mathrm{j}$ 年目に保全デー夕を保有する建物の総延べ床面䄼 $\mathrm{Mj}$ : 稼動年数 $\mathrm{n}$ 年目の建物 $\mathrm{j} に お け$ 万保全費

${ }^{* 1}$ 国士涻大学工学部建築デザイン工学科 講師・工博

*2 早稲田大学大学院理工学研究科建築学 修士課程

*3 侏ザイマックス 工修

*4 早稲田大学理工学部建築学科 教授・工博
図 1 に用途別建物の延べ床面積 $1 \mathrm{~m}^{2}$ 当たりの累積保全費推 計值を示す。図1より、稼動年数 15 年目において、警察・郵便 局の 2,045 円 $/ \mathrm{m}^{2} 、$ 老人ホームの 1,989 円 $/ \mathrm{m}^{2}$ 、病院・保健 所の1，838円 $/ \mathrm{m}^{2}$ と高く、全体平均は999日 $/ \mathrm{m}^{2}$ 、事務所で は875円 $/ \mathrm{m}^{2}$ と平均よりも低い。

空調対象者が弱者である老人ホーム、病院・保健所の保全 費が高く、一般的な人が利用している事務所の保全費が低い。 自動制御機器の単位面積当りの設置数は、メーカーへのヒアリ ングより病院で約 0.014 点 $/ \mathrm{m}^{2}$ 、事務所で約 0.010 点 $/ \mathrm{m}^{2}$ であ

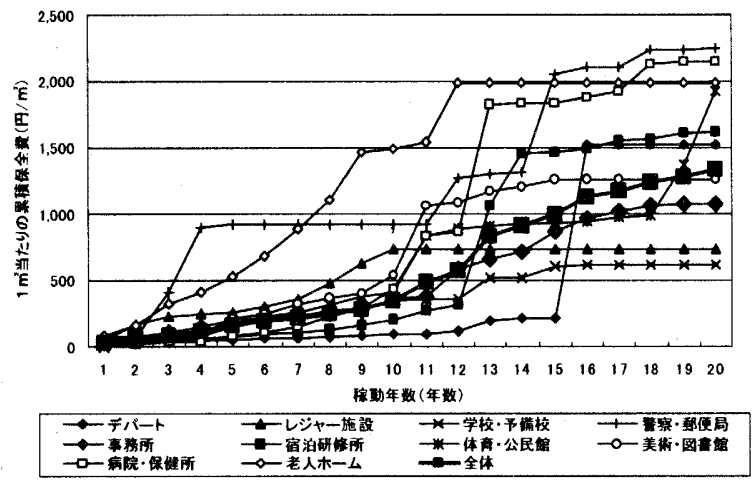

図 1 用途別建物の自動制御機器の推定累掼保全費
Asst. Prof., Dept. of Architecture, Kokushikan University, Dr. Eng. Architecture, Graduate School of Science and Engineering, Waseda University Zymax Co., Ltd., M. Eng.

Prof., Dept. of Architecture, Waseda University, Dr. Eng. 
る。自動制御機器の故障率が建物用途により変化しないと仮定 すると、自動制御機器の故障による空調設備への影響が空調 対象者の許容範囲内に収まる場合には保全が行われず、事務 所ビルにおいて故障が放置され、潜在化していることを示晙し ている。

快適空気調和における空調自動制御システムの目的は、室 内にいる人間の大多数がほぼ满足できるような室内環境を維 持し、また空気調和設備の動作を効率的に行なうことによりエ ネルギー消費量を抑制することである。

そこで本研究では、空調自動制御システムの運用時におけ る経済的価值を定量化し、システム機能維持の経済性評価手 法を提案する。はじめに、空調自動制御システムの潜在化故障 によるシステム性能劣化率の算出手法を提案する。次に、快適 空菏システムの正常運転確保の価值を定量化し、空調自動制 御システムによる省エネルギー効果の算出手法を示す。最後に 事務所ビルにおけるケーススタディを行い、空調自動制御シス テムの機能維持における経済性評価を行う。

\section{2. 空調自動制御システムの価値算出概念}

図1より自動制御システムの性能に影響を与える故障には、 自動制御システムの警報や、利用者の日常巡回点検（外観確 認)により発見される故障 (顕在化故障) と自動制御機器の据 付・作動状況の目視確認や、デー夕確認し異常が発見できるよ うな故障 (潜在化故障)の 2 つのパターンがある。顕在化故障は 故障が発見されやすい為、故障から発見までの時間が比較的 短期間であるが、潜在化故障は使用時間の経過と共に故障が 蓄積され、快適空調システム全体の性能に影響を与えることを 意味する。特に潜在化故障は、図1の結果が示すように、発見 されたとしても人為的に全てが修絴されるとは限らないため、経 年とともに蓄積され、結果としてシステムの性能を少化させる。

一方で、税法上、快適空調システムの経済的価值は、快適空 諎システムを製造するのに費やした費用と等価であるが、その 経済的価值は時間とともに償却していき、最終的には残存価值 のみとなる。この経済的価值は、システムのハード的経済価值と 言え、システム機能が停止してもハード的価值は残る。しかし、 保全の目的が初期性能を維持する行為であることから、機能維 持の経済的価值は、快適空調システムの正常運転によって生じ る価值を考える必要がある。つまり、空調自動制御システムの機 能維持は、快適空調システムの正常運転確保による価值と省エ ネルギー機能による光熱費削減効果を生じることになる。

空調自動制御システムの性能劣化は、経午と共に加速度的 に進行する。機能維持は性能劣化を初期性能まで向上させる 行為であるので、性能劣化による快適空菏システムの正常動作 によって生じる価值損失を回避させる行為と考えられる。よって 機能維持の価值は、機能維持の無い場合に発生しうる性能劣 化による価值損失の累積值と等価であると言える。空調自動制 御システムの機能維持における経済的価值を算出する為には、 機能維持の無い場合に発生しうる快適空謌システムの正常運 転確保による価值の損失と省エネルギ一機能による光熱費削 诚効果の損头を定量化する必要がある。

\section{3. 自動制御システム劣化率の算定手法}

\section{1 故障時に発生する現象の実態調查}

自動制御機器の故障時に発生する現象として、室内環境へ の影響がある。室内環境への影響は、快適空調システムの機能 的損失となる。自動制御機器単体の不具合により、直接的、間 接的に室内環境に影響を及ぼす確率を影響度とする。ここで、 自動制御機器メーカーの保全サービスマンを対象に機器故障 時の各機能への影響度についてヒアリングアンケート調查を 行った。結果、故障事例 234 件のうち、空調自動制御機器に関 するものは75件であった。各故障事例において、自動制御機 器の故障時における「室内環境への影響」が確実にあると考え られる場合のみ「あり」とし、有無を判断できない場合は「なし」 に含んでいる。

以上の調查結果から、各機器の故障事例数を分母とし、そ のうち室内側に影響が現れた機器個数を分子とした割合を影響 度 $\alpha$ とする。各機器の影響度を表 1 に示す。影響度は、湿度セ ンサが 0.75 と高く、多くの機器において0.5を超えていること が明らかとなった。

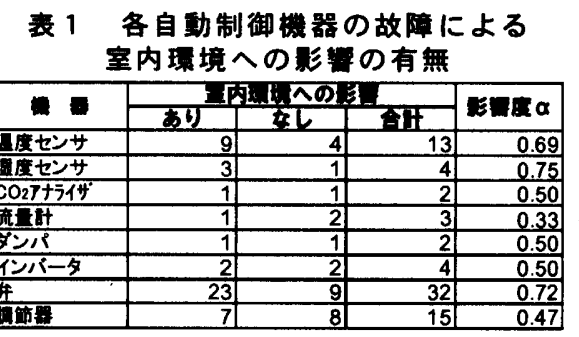

3. 2 各機器の不信頼度の算出

各自動制御機器の不信頼度について信頼性関数である、累 積ハザード・ワイブル分布関数を用いて算出する。

ワイブル分布の式を以下に示す。

$$
\mathrm{F}(\mathrm{t})=1-\mathrm{e}^{-\left(\frac{\mathrm{t}}{\eta}\right)^{\mathrm{m}}} \quad M T T F=\eta \Gamma\left(1+\frac{1}{m}\right)
$$

$\mathrm{F}(\mathrm{t})$ : 不信頼度、 $\eta$ : 尺度パラメータ、 $\mathrm{m}$ : 形状パラメータ

不信頼度算出に用いたデータは、各機器についての点検履 歴及び繁急保全履歴である。点検履歴は、メンテナンスの専門 家が自動制御機器の据付・作動状況を目視確認や、デー夕確 認し異常を発見した履歴であり、潜在化故障履歴である。それ に対し、緊急保全履歴とは、建物管理者の日常点検や、建物 利用者からの情報により発見された故障で、即時に修縓が求 められる故障であり顕在化故障履歴である。

本分析で用いた建物概要を表 2 に示す。調查対象ビルは、1 984 年から1996 年に竣エした 17 棟の事務所ビルであり、調 查対象の機器点数は 24,023 点である。不信頼度の算出は、 点検履歷と緊急保全履歴を用いた。また、自動制御機器を非修 理系として分析を行った。分析によって得られる関数 $\mathrm{F}(\mathrm{t})$ は、 全ての故障発生数 (累積)の全機器数に対する割合の経時変 化 (以下、故障発生に関する不信頼度)を意味する。

室内・空調機系の自動制御機器の形状パラメー夕 $\mathrm{m}$ と尺度パ ラメータ $\eta$ 及びMTTFの算出結果を図 2 に示す。また、熱源趈 り系統の自動制御機器の形状パラメータ $\mathrm{m}$ と尺度パラメータ 
及びMTTFの算出結果を図3に示す。

図2より、検出部では、温度センサーのMTTFが59.7 年と 長く、次いで湿度センサーの41.8 年となる。 $\mathrm{CO}_{2}$ アナライザ は15.4 年とMTTFが最も短い。調節器は、デジタル式が最も 長く33.5 年となる。操作器ではダンパが 38.7 年、弁は 22.9 年である。全体として、検出部全体が35.5年と最も辰く、損作 器が23.6年と最も短い。

図3より、熱源奋り系統のMTTFは、変換器が長く59.4年 である。次いで温度センサーの5 2.4 年となっている。また、流 量計が 17.6 年と熱源趈り系統の中では、故障しやすいことが わかる。室内・空調機系統と比較して、温度センサーは約 5 午 短い。また検出部全体では、約 7 年短い。諯節器は、電子、デ ジタル式ともに室内・空調機系統よりも短いが、全体では、33. 4 年と約 5 年長い。変換器も同様の傾向にあり、約 25 年長い。 操作器は、弁が 31.9 年と室内・空調機系統に比べ約 9 年辰 い。全体でも 34.7 年と約 11 年長い。

図4に自動制御機器全体の故障発生に関する不信頼度を示 す。

図4より、不信頼度が高いのは操作器であり、MTTFは24年 と短く、また稼動 20 年目において不信頼度は 0.32 となってい る。次いで調節器が高くMTTFは28.3年となっているが、稼 動 20 年目までは、検出部の方が不信頼度が高く、稼動 20 年 目において、検出部、調節器はそれぞれ、0.21と0.20となっ ている。変換器の不信頼度は低く、MTTFは37，7年であり、 稼動 20 年目において0.10となる。

同様に、各機器の緊急保全履歴を用いて顕在化する故障発 生数 (累積)の全機器数に対する割合の経時変化の関数 $\mathrm{M}(\mathrm{t})$ (以下、顕在化故障に関する不信頼度)を算出した。

3. 3 自動制御システムの性能劣化率の算出手法の提案

自動制御システムは、温度制御やCO 2 制御といった機能から 構成され、各機能は、温度センサーや操作器といった機器で構 成される。時刻 $\mathrm{t} に お け る$ 空調システムの正常運転確保の価値 損失及び省エネルギー効果損失は、機能単位で発生し、自動 制御システムを構成する全機能数のうち不具合を発生した機能 数の割合に比例すると考えられる。よって本研究において自動 制御システムの性能劣化率 $\mathrm{Pc}(\mathrm{t})$ は、時刻 $\mathrm{t}$ における機能維持 を行わなかった場合のシステム中に存在する機能の累積不具 合発生数の割合と定義できる。また各機能の空調システムの正 常運転確保と省エネルギ一効果への影響は、明確に分離する ことは出来ず、等価の影響を与えていると考えられる。

自動制御システムの性能劣化率を算出するには、各機能の

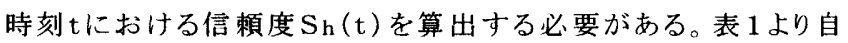
動制御機器の故障の全てが機能に影響を与えているとは限ら ない。また、顕在化故障は、故障発見時から修繮時までの時間 が短いことから、機能一影響を与える要甘とはならない。よっ て、機能に影響を与えない潜在化故障の機器および正常に作 動している機器数 (累積)の全機器数に対する割合の経時変化 (以下、機能に影響を与える潜在化故障に関する信頼度) 関数 $\mathrm{Ri}(\mathrm{t})$ は、3.2 節で算出した各機器の故障発生に関する不信 頼度 $F(t)$ と顕在化故障に関する不信頼度 $M(t)$ 上り、F(t)か
表 2 調查对象建物概要

\begin{tabular}{|c|c|c|c|}
\hline 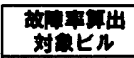 & 蛙工年 & ( $\left.\mathrm{m}^{\mathrm{n}}\right)$ & 唇 2 \\
\hline AEU & 1984年 3 月 & 8,060 & 2,608 \\
\hline Bビル & 1984年 & 51,941 & 1,956 \\
\hline CEU & 1985年 11 月 & 11,480 & 393 \\
\hline Dビル & 1987年 3月 & 18,147 & 919 \\
\hline Еビル & 1987年 10 月 & 8,000 & 78 \\
\hline FEル & 1987年 10 月 & & 650 \\
\hline GEル & 1988年 6 月 & 5,000 & 305 \\
\hline Hビル & 1987年 10 月 & 34,326 & 1,507 \\
\hline EU & 1989年 3月 & 50,925 & 1,667 \\
\hline Jビル & 1991年 6月 & 10,000 & 284 \\
\hline KEル & 1991年 5月 & 14,333 & 78 \\
\hline LE゙ル & 1987年 2月 & & 109 \\
\hline MËル & 1991年 6月 & 9,982 & 200 \\
\hline NEU & 1995年 4月 & 119,000 & 205 \\
\hline Oビル & 1996年 2月 & 54,679 & 1,592 \\
\hline PEL & 1995年 1月 & 239.000 & 9.885 \\
\hline Qヒル & 1992年 5月 & 35,000 & 1,587 \\
\hline
\end{tabular}

\begin{tabular}{|c|c|c|c|c|}
\hline & 는 & $m$ & $\pi$ & MTTF \\
\hline \multirow{5}{*}{ 検出部 } & 温度センサー & 2.156 & 67.454 & 59.7 \\
\hline & 温瀑废センサー & 2.395 & 35.306 & 31.3 \\
\hline & 理庭センサー & 1.861 & 47.091 & 41.8 \\
\hline & $\mathrm{CO}_{2} \boldsymbol{P}+51+f$ & 2.244 & 17.369 & 15.4 \\
\hline & 绕出部全休 & 2.407 & 40.077 & 35.5 \\
\hline \multirow{4}{*}{ 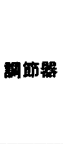 } & 䒠氛式 & 2.575 & 30.414 & 27.0 \\
\hline & 㥞子式 & 2.212 & 36.751 & 32.5 \\
\hline & デジタル & 3.025 & 37.453 & 33.5 \\
\hline & |畗第櫘全休 & 3.256 & 31.560 & 28.3 \\
\hline 変橹器 & 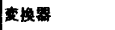 & 3.344 & 38.813 & 34.8 \\
\hline \multirow{3}{*}{ 操作器 } & 井 & 3.122 & 25.644 & 22.9 \\
\hline & அンパ & 2.853 & 43.471 & 38.7 \\
\hline & 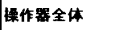 & 3.299 & 26.327 & 23.6 \\
\hline
\end{tabular}

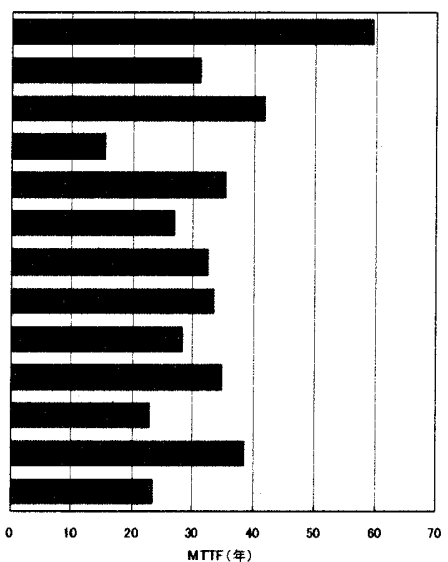

図 2 室内・空調機系自動制御機器のMTTF算出結果

\begin{tabular}{|c|c|c|c|c|}
\hline & 部 & $m$ & $\eta$ & WTTF \\
\hline \multirow{3}{*}{ 模出部 } & 温度センサー & 2.251 & 59.150 & 52.4 \\
\hline & 流垔部 & 5.797 & 19.017 & 17.6 \\
\hline & 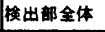 & 3.326 & 31.487 & 28.3 \\
\hline \multirow{3}{*}{ 粡第 } & 電子式 & 3.581 & 27.410 & 24.7 \\
\hline & デシタル & 2.014 & 22.826 & 20.2 \\
\hline & 略笛器全体 & 2.032 & 37.741 & 33.4 \\
\hline 交埃器 & 交换箖 & 1.998 & 67.072 & 59.4 \\
\hline \multirow{2}{*}{ 操作器 } & 䄯 & 2.163 & 36.072 & 31.9 \\
\hline & 缘作亚全体 & 2.153 & 39.150 & 34.7 \\
\hline
\end{tabular}

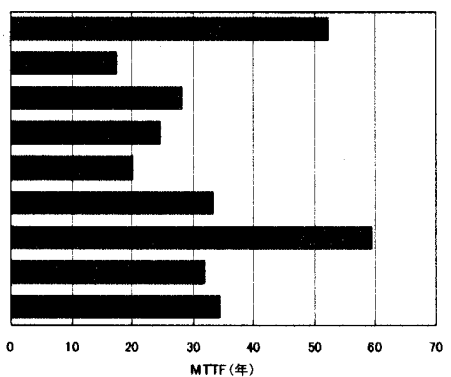

图 3 熱源趈り系統自動制御機器のM T T F

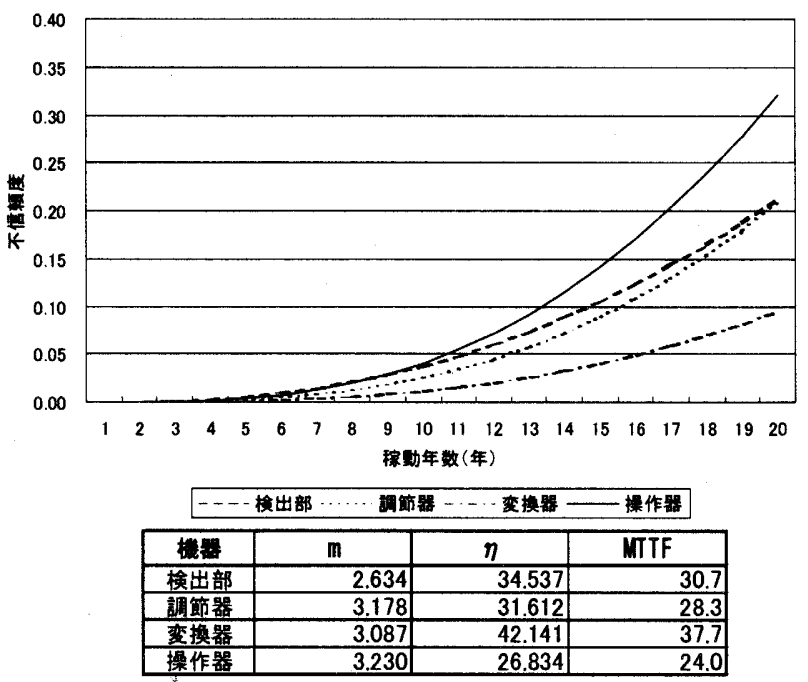

図 4

自動制御機器全体の故障発生に関する不信頼度 
$ら \mathrm{M}(\mathrm{t})$ を減算し、また機器の故障は必ずしも機能への影響が あるとは限らないことから、この結果に影響度 $\alpha$ を掛けた值を1 から引いたものとなる。各機器の機能に影響を与える潜在化故 障に関する信頼度関数Ri（t)の算出式を以下に示す。

$$
R_{i}(t)=1-\{F(t)-M(t)\} \alpha \cdots(1)
$$

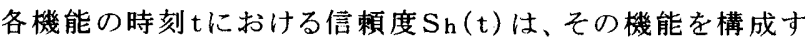
る機器が直列系をなすという立場をとり、機能に影響を与える潜 在化故障に関する信頼度関数 $\mathrm{Ri}(\mathrm{t})$ を用いて以下の式で表せ る。

$$
S_{h}(t)=\prod_{i=1}^{n} R_{i}(t) \quad \cdots(2)
$$

時刻 $\mathrm{t}$ におる自動制御システムの性能 $\mathrm{P}(\mathrm{t})$ をシステムを構 成する全機能数のうち正常に作動している機能数の割合と定 義する。よって、時刻 $\mathrm{t}$ における自動制御システムの性能 $\mathrm{P}(\mathrm{t})$ は、(1) 式と (2) 式より各機能の信頼度 $\mathrm{S}_{\mathrm{h}}(\mathrm{t})$ を算出し、この $\mathrm{S}_{\mathrm{h}}$ (t) の和とシステム全体の機能数 $\mathrm{m}$ より、(3) 式を用いて算出す る。

$$
P(t)=\frac{1}{m} \sum_{h=1}^{m} S_{h}(t) \cdots(3)
$$

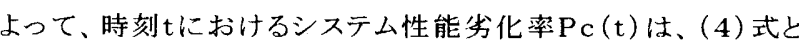
なる。

$$
P c(t)=1-P(t) \cdots(4)
$$

\section{4, 快適空調システムの正常運転確保の経済性評価}

\section{1 仮想市場評価法 ( C VM) 概要}

本研究において利用者の要求を考慮した快適空㑉システム の正常運転確保の価值を評価するために、賃貸事務所ビルの 利用者に対LCVM (仮想市場評価法:Contingent Valuation $\mathrm{M}$ e $\mathrm{t} \mathrm{h}$ o d ) )用いたアンケート調查を行った。この手法は、主に自 然環境の経済的価值を評価し、環境保全に役立てる目的で多 く利用されているものである。

人間を取り巻く環境・サーービスの価值を経済的に評価する手 法は、計量経済学の分野でさまざまな手法が考案されている が、調查手法の分類として大きく顕示選好法と表明選好法に分 けられる。

快適空調システムの正常運転確保の価值評価において、顕 示選好法による評価は工事費や建物価格などを参考に算定す ることにより比較的容易に行うことができる。しかし、利用者の 要求を反映した評価を行うため、本研究では表明選好洁による 調查を行うこととした。以下にCVMの特徴と利点をまとめる。

I 既存のデータの有無とは関係なく、理論上あらゆる財の評 価に適用可能である。

II 非利用価値の評価が可能である。

III 評価額は受益者のWTP (支払意思額)から集計されたもの なので、回答者の合意点を表している可能性がある。

\section{2 調查方法および調查票}

CVMの特徵をふまえ、本調查の調查対象および評価対象 の特徵から、以下のような方法で調查票を作成することとした。
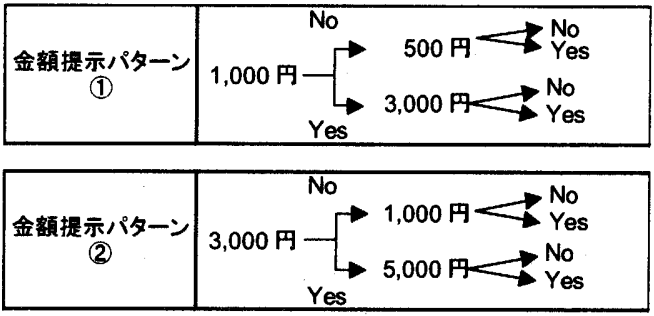

\begin{tabular}{|c|c|c|}
\hline DIIthr & 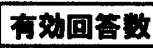 & 主存空 \\
\hline Rビル & 5 人 & ビル用マルチパッケージエアコン \\
\hline Sビル & 33 人 & セントラル(吸収式冷温水発生機) \\
\hline Tビル & 27 人 & 地域冷暖房、FCU \\
\hline Uビル & $117 \curlywedge$ & セントラル(吸収式冷温水発生機) \\
\hline 合部 & 182 人 & \\
\hline
\end{tabular}

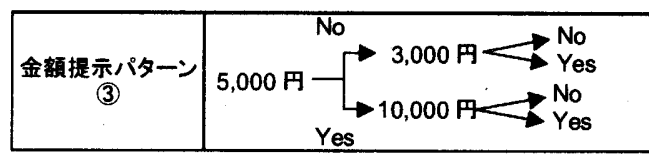

图 5 C V Mアンケート 支払意志额金䫫提示設定

表 3 各建物の有効回答数

・質問方式: 二段階二肢選択方式 (ダブルバウンド)

・支払い手段: 空調サービス保険 (年額: 円 /年・人)

回答者に、回答時点で空調が停止し翌日まで復旧しなかっ た状態を想像してもらう。入居しているビルが、そのような事態 が発生しないようにするための空調サービス保険に加入すると した場合に、その保険にいくら支払ってもよいか（支払意思額） を調查する。よって、本調查で得られた支払意思額は、利用者 の快適空気調和システムが正常運転することによって得られる 利益に対する価値と捉えられ、快適空気調和システムの正常運 転確保の価值と等価である。また統計処理の精度を向上し、限 られたサンプル数からより適切な結果を得るため、ダブルバウン ドによって提示する金額のパターンを 3 種類用意した。提示金 額を図5に示す。

\section{3 C VM調查結果}

仮想市場評価法による支払意志額の算定は、市販のソフト ウェア 2 による。二段階二肢選択方式を用いた調查票により、ア ンタート調查を行った。調查期間は、2003午6月から9月であ る。調查方式は訪問留置方式を採用した。

各建物の有効回答数を表 3 に示す。集計は、これらすべての 建物からの調查票をす心てて合計して集計した支払意志額の他 に、個々の建物ごとの支払意志額も算定した。本来、仮想市場 評価法による支払意志額は、調查対象場所を限定して行われ るのが普通であるが、今回は単一の建物内で有効な回答数を 得ることが困難であるため、複数の建物からの結果を合計して 集計するものとした。

ただし、個々の建物における支払意志額はサンプル数が限 定されており、集計に際して有効と考えられる水準に達していな いため、信頼度は高くないものと考えられることを付記する。特 にRビルにおいて、回答数が少ないために単独では集計が不 可能であった。全体およびそれぞれの調査対象建物における 支払意志額を図6に示す。

建物ごとの集計結果をみると、アンケートを行った建物による 支払意志額の違いはそれほど大きくなく、建物側の要因により 


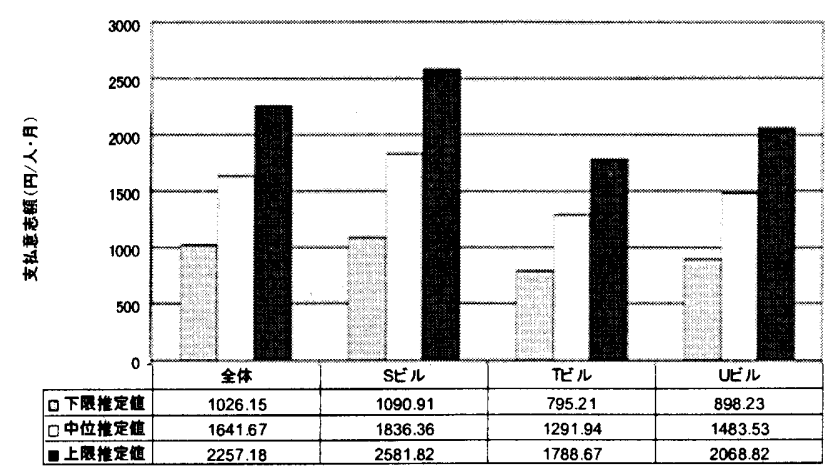

图 6 支払意志額の推定結果

結果に大きな誤差は生じていないと考えられる。よって、全体の 回答をまとめて集計した支払意志額は、同一の建物から得られ た回答ではないが、建物固有の条件による大きな結果の格差 を含んでおらず、支払意志額として採用して差し支えないと考え られる。

仮想市場評価法における支払意志額は、通常下限推定值を 代表して支払意志額とするのが一般的である。これは、支払意 志額の過大評価を防ぐためである。今回も下限推定值を採用 し、空諎システムの正常運転確保の経済的価値は、1026.15

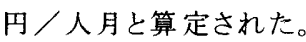

単位面積あたりの価值を求めるため、一般的なオフィスビル における単位面積あたりの在室人数を設定する。(社) 日本ビル ヂング協会の調查 ${ }^{3)}$ によるオフィスワーカーー人あたりの床面積 調查結果より、多少地域による差が見られるが、全国の平均値 と東京の平均值に関してはそれほど差がないことから、全国で の平均值を採用し、一人あたりの床面積は $13 \mathrm{~m}^{2}$ であるとする。 以上より、単位面積あたりの空㑉システムの正常運転確保の経 済的価值は、78.93円 $/ \mathrm{m}^{2}$ 月となる。

4. 4 自動制御システムの性能劣化による空調システム の正常運転確保の価値損失の算出手法

4. 3節のCVMの結果による空調システムの正常運転確保 の価値は、1日の空調停止状態を回避する価値である。機能に 影響を与える自動制御機器の故障の蓄積によって、空調システ ムは正常運転状態と空調停止状態の中間の状態で運転される ことになる。本研究では、CVMの結果を単位時間当たりの空 調システムの正常運転確保の価値と捉える。自動制御システム
の性能劣化による空調システムの正常と停止の中間状態運転 は、正常運転確保の価值を部分的に損头させていることにな る。この部分的な価值損失は、自動制御システムの劣化率 P c (t)に比例すると定義する。よって、CVMの結果による単位時 間当たりの空調システムの正常運転確保の価値をV1とすると、 時刻 $\mathrm{t}$ における自動制御システムの性能劣化による空調システ ムの正常運転確保の価値損失LV1は、(4) 式を用いて以下の 式より算出できる。

$$
L V_{1}=V_{1} \cdot P c(t) \cdots(5)
$$

\section{5．省エネルギー機能による経済性評価}

5. 1 省エネルギー効果算出手法

自動制御システムによる省エネルギー効果は、外気冷房制 御、CO2制御、VAV制御、熱源搬送ポンプインバータ制御、 最適起動停止制御とする。各制御項目における省エネルギー 効果の算出は、基本的にこれらの制御項目の導入前と導入後 の差である。これら5項目の省エネルギー効果の算出式を表 4 に示す。

外気冷房制御による省エネルギー効果は、主に中間期（室 内に対して外気エンタルピが低いとき)において、設計外気量 よりも多くの外気を導入することにより、空諎機冷水負荷を削減 し、年間冷熱製造量を低減させる。ただし冬期においては、加 湿負荷の増大があるため導入外気の下限值があり、推奨值で は $10^{\circ} \mathrm{C}$ とれる。

$\mathrm{CO}_{2}$ 制御も同様に、室内の $\mathrm{CO}_{2}$ 濃度がある基準を超えない 範曲で外気導入量を削減する制御である。これにより、外気負 荷を最小限に抑えることが可能になる。

VAV制御は、給気温度を変化させる代わりに、給気風量を 変化させることによって、室内に対する供給熱量を変化させ、 室内負荷を処理する。このため、負荷が小さいときには搬送動 力を大幅に削減することができる。

熱源搬送ポンブインバー夕制御は、熱源の搬送用ポンプに インバータを導入し、電源の周波数を変化させることにより、吐 出圧制御を行う。これにより、バイパス流量に費やされる軸動 力が減少し、省エネルギーを図ることが可能になる。

最適起動停止制御は、対象部屋の温度状況に応じた最適な

表 4 自動制御システムによる省エネルギー効果

\begin{tabular}{|c|c|c|c|c|}
\hline 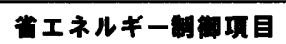 & 社エネルキー效果 & \multicolumn{3}{|c|}{ 年出式 } \\
\hline 外每冷房制御 & 外気利用により、勄源製造繁量の削减した量 & $S E=\Delta e \cdot O A \cdot q \cdot 10^{3}$ & $\cdots(\mathrm{i})$ & 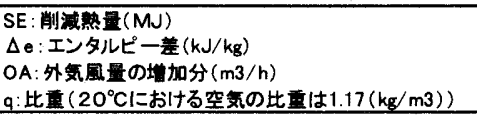 \\
\hline CO2制御 & 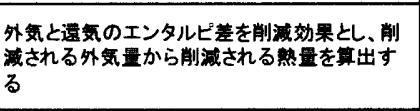 & $S E=\Delta e \cdot O A \cdot q \cdot 10^{3}$ & $\cdots($ ii $)$ & 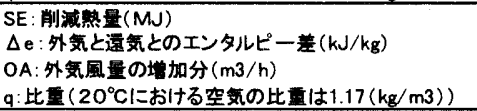 \\
\hline VAV制御 & 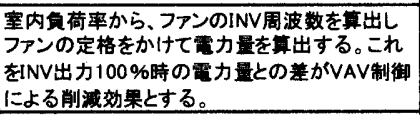 & $S E=H l \cdot k W \cdot \lambda$ & $\cdots($ iii $)$ & 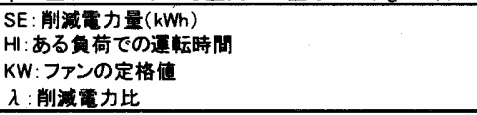 \\
\hline $\begin{array}{l}\text { 熱源搬送ボンプータ制御 } \\
\text { インバー }\end{array}$ & 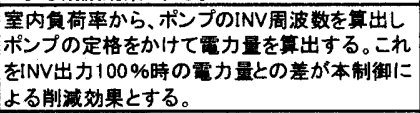 & $S E=H l \cdot k W \cdot \lambda$ & $\cdots$ (iv) & 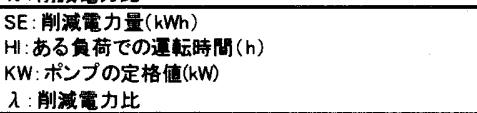 \\
\hline 蔇適起動停止制御 & 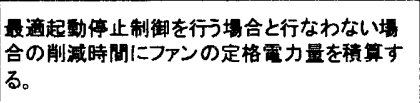 & $S E=\frac{(H m-H n)}{60} \cdot k W$ & $\cdots(v)$ & 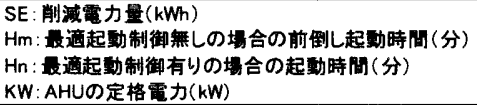 \\
\hline
\end{tabular}


時刻に空調機を起動する制御である。これにより、空調機の起 動前倒し時間を最小にし、ファン動力を削減することができる。

5. 2 自動制御システムの性能劣化による省エネルギー 効果損失の算出手法

自動制御システムの性能劣化による省エネルギー効果の損 失は、各機能の不具合による省エネルギー効果一の影響を等 価とした場合、自動制御システムの性能劣化率 $\mathrm{Pc}(\mathrm{t})$ に比例寸 る。よって、5．1節で算出された効果を $\mathrm{V}_{2}$ とし、時刻 $\mathrm{t}$ における 自動制御システムの性能劣化による省エネルギー効果損失を $\mathrm{L}$ V 2とすると、LV2は以下の式より算出される。

$$
L V_{2}=V_{2} \cdot \operatorname{Pc}(t) \cdots(6)
$$

\section{6. 機能維持の経済性評価ケーススタティ}

本ケーススタディ対象の建物概要を表5、自動制御機器点数 及び不信頼度関数等各種設定值を表 6 に示寸。ケーススタディ 対象は、約 $3 千 \mathrm{~m}^{2}$ 事務所用途仮想ビルである。本ケーススタ ディを通じて、自動制御システムの機能維持の経済性評価を行 なう。また、ケーススタディ対象のモデルビルは、実在するビルと 仕様を同じくしている。この寒在するビルには、外気冷房制御、 $\mathrm{VAV}$ 制御、 $\mathrm{CO} 2$ 制御、熱源搬送ポンプインバータ制御、最適 起動停止制御が機能として設定されており、本ケーススタディの 省エネルギー効果の算出には、本ビルの 2002 年における計 測データを用いて算出する。

\section{1 自動制御システムの性能劣化率の算出}

本ケーススタディにおける制御機器点数は、熱源、空調合わ せて498点ある。機能数は、309機能である。機能数及び構成 例を表 7 に示す。

制御機器 1 点が複数の機能を受け持っているため、1 機能当 りの平均機器点数は、6.05点となる。(1) 式より各機器の信頼

\begin{tabular}{|c|c|c|}
\hline I 目 & & \\
\hline 名 称 & モデルビル（立圷 & :東京都内) \\
\hline 階 数 & 9階 & \\
\hline 空調設備 & \multicolumn{2}{|c|}{ 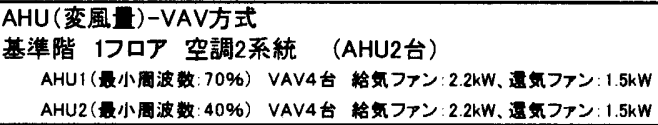 } \\
\hline 熱源設備 & 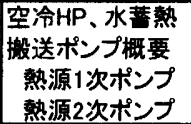 & $\begin{array}{l}\text { 最低周波数 } 40 \% \\
\text { 熱交換器容且 } 386.8 \mathrm{MJ} / \mathrm{h}\end{array}$ \\
\hline \multirow{3}{*}{ 延床面積 } & 1階部分 & $337.79 \mathrm{~m}^{2}$ \\
\hline & 基萑階 (2〜9階) & $321.41 * 8=2571.28 \mathrm{~m}^{2}$ \\
\hline & 建物全体 & $2909.07 \mathrm{~m}^{2}$ \\
\hline
\end{tabular}

表 6 自動制御機器点数及び各種設定值

\begin{tabular}{|c|c|c|c|c|c|c|c|c|c|}
\hline \multirow[b]{2}{*}{ 系繶 } & \multirow[b]{2}{*}{ 分靠 } & \multirow[b]{2}{*}{ 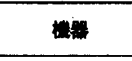 } & \multirow{2}{*}{ 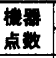 } & \multicolumn{2}{|c|}{$F(t)$} & \multicolumn{2}{|c|}{$M(t)$} & \multirow[b]{2}{*}{ E난 } & \multirow[b]{2}{*}{ ints } \\
\hline & & & & $\mathrm{m}$ & $\pi$ & $\mathrm{m}$ & $n$ & & \\
\hline \multirow{10}{*}{ 至内·空拥機 } & \multirow{5}{*}{ 模出部 } & その他 & 96 & 2.407 & 40.077 & 1.964 & 114.399 & 0.64 & 検出部全体の值を用いる \\
\hline & & 温度センサー & 85 & 2.156 & 67.454 & 2.225 & 116.589 & 0.69 & \\
\hline & & 温湿庭センサー & 33 & 2.395 & 35.306 & 2.762 & 34.350 & 0.64 & \\
\hline & & $\mathrm{CO}_{2}$ アナライザ & 32 & 2.244 & 17.369 & 1.441 & 68.617 & 0.50 & \\
\hline & & 压カセンサー & 4 & 2.407 & 40.077 & 1.964 & 114.399 & 0.64 & 梌出部全体の值を用いる \\
\hline & \multirow{2}{*}{ 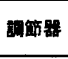 } & その地 & 1 & 3.256 & 31.560 & 2.568 & 89.954 & 0.47 & 的策器全体の隹を用いる \\
\hline & & デシタル & 45 & 3.025 & 37.453 & 2.952 & 60.083 & 0.47 & \\
\hline & \multirow{3}{*}{ 㩰作咏 } & 屏 & 64 & 3.122 & 25.644 & 2.116 & 130.514 & 0.72 & \\
\hline & & 处パ & 108 & 2.853 & 43.471 & 3.265 & 72.938 & 0.50 & \\
\hline & & インバータ & 4 & 3.299 & 26.327 & 2.415 & 103.275 & 0.50 & 推作賏全体の隹を用いる \\
\hline \multirow{6}{*}{ 烸源迵以 } & \multirow{3}{*}{ 㛟业部 } & Zの他 & 1 & 3.326 & 31.487 & 2.222 & 116.623 & 0.64 & 换出部全体の值を用いる \\
\hline & & 罝度センサー & 7 & 2.251 & 59.150 & 2.198 & 99.814 & 0.69 & \\
\hline & & 压カセンサー & 1 & 3.326 & 31.487 & 2.222 & 116.623 & 0.64 & 揁出部全体の值を用いる \\
\hline & 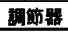 & デシタル & 7 & 2.014 & 22.826 & & & 0.47 & \\
\hline & \multirow{2}{*}{ 摷作堣 } & 井 & 5 & 2.163 & 36.072 & 1.201 & 742.404 & 0.72 & \\
\hline & & インバータ & 4 & 2.153 & 39.150 & 1.198 & 856.916 & 0.50 & 稒作器全体の值 \\
\hline
\end{tabular}

\begin{tabular}{|c|c|c|c|}
\hline 力制御 & & 4 & $2 x$ \\
\hline Intron & $\operatorname{man}$ & then & $\frac{1}{10}$ \\
\hline$\infty_{\text {2制到 }}$ & & 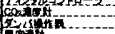 & $\cdots$ \\
\hline VAV制部 & & 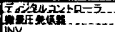 & $\ldots$ \\
\hline 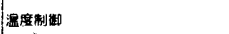 & & 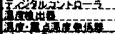 & 年 \\
\hline 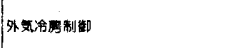 & & 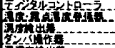 & $\ldots-1$ \\
\hline 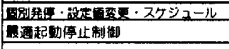 & & 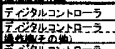 & 3 \\
\hline 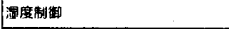 & & 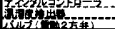 & $+\cdots$ \\
\hline 送水湿度制對 & & 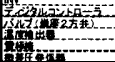 & 等 \\
\hline 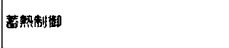 & & 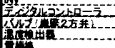 & $-a_{1}$ \\
\hline 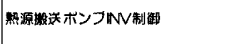 & & 筀籍 & 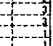 \\
\hline 合 社 & 309 & & \\
\hline
\end{tabular}

度を算出し、（2）式より、各機能における経年による性能劣化を 算出する。最後に (4) 式より自動制御システムの経年による性 能劣化率を算出した。

図 7 に、自動制御システムの性能劣化率の経年変化を示す。 図よりシステム性能劣化率は、初期性能を 1 とした場合、稼働 15 年目に0.66、稼働20年目では0.35となる。

6. 2 空調システムの正常運転確保の価値及び省エネル ギー効果の算出

4節のCVMの結果より空調システムの正常運転確保の価値 は、78.93円 $/ \mathrm{m}^{2}$ 月となり、本ケースでは年間で $2,755,35$ 5 円 /年となる。

次に自動制御システムによる省エネルギー効果の算定を行 なう。本ケーススタディに怙ける自動制御システムの省エネル ギ一項目は、外気椧房制御、CO2制御、VAV制御、熱源搬送 ポンプインバータ制御、最適起動停止制御の5 項目となる。

まず初めに、実在するビルの1フロアにおける冷房・暖房負 荷率の時刻別変動を 2002 年における計测データより算出し た。冷房・暖房負荷率は、1フロアにおける冷熱最大量、温熱最 大量を分母とし各時間における冷熱量、温熱量の割合から算 出する。算出結果を図8に示す。また、ポンプ負荷を算定する 場合、一次ポンプ系統及び二次ポンプ系統における 2002 年 熱交換器の最大熱交換量を分母としてその割合より算出する。 各時間におけるポンプ負荷の算出結果を図 9 に示す。また電 力、冷熱及び温熱の単価設定を表8に示す。

また外気導入量は、1フロアにおける空調機 2 台の各時間の 外気導入ダクト断面積 $\left(0.18 \mathrm{~m}^{2} 、 0.24 \mathrm{~m}^{2}\right)$ と風速データ、外気 ダンパ開度データより推定する。それぞれの算出結果の和を 1 フロアの外気導入量とする。算出結果を図10に示す。

外気冷房制御の冷熱削减効果及び $\mathrm{CO} 2$ 制御の冷熱・温熱 削減効果の算出を行う。これらの制御は、本制御が導入されな い場合の設計外気量に対し、導入量が多ければ外気冷房制御 の効果となり、少ない場合は $\mathrm{CO} 2$ 制御による効果となる。ただ し、外気冷房制御の効果の場合、迸入外気条件の有効範囲と して、外気温度 $10^{\circ} \mathrm{C}$ 以上及び露点温度 13 度以下を満たす外 気とする。効果は表 4 の（i ）式、（ii )式より、有効籁囲にある外 気導入 (削堿) 量に外気と空内環境とのエンタルピ差 $\Delta \mathrm{e}$ を掛け た熱量となる。設計外気導入量及び室内環境条件を表 9 に示 す。また外気条件は、2002年の東京における計測デ一タを用 の計測データである各時間の熱交換器における熱交換量より、 


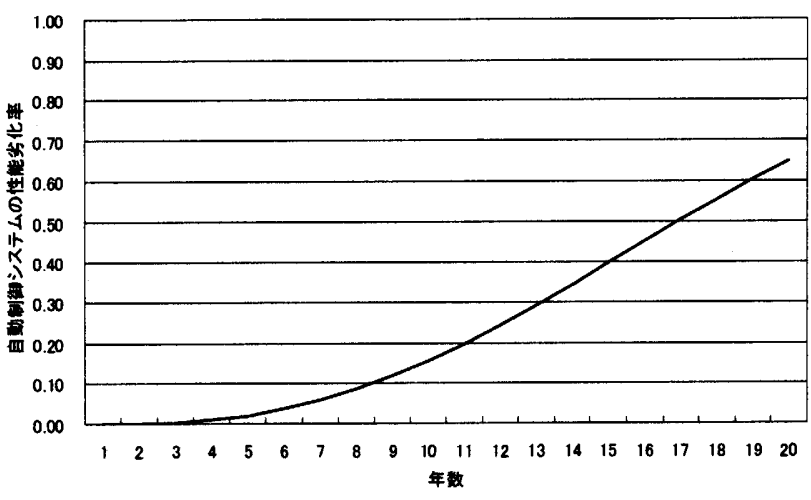

図 7 自動制御システムの性能劣化率の算出

いる。図10の結果より算出した結果、外気冷房による冷熱削減 効果は2，233 MJ/年・階、 $\mathrm{CO} 2$ 制御による冷熱削減効果は1 $3,280 \mathrm{MJ} /$ 年・階、温熱削隇効果は $10,094 \mathrm{MJ} /$ 年・階とな る。本ケーススタディでは、簡易的に各フロアーともに同条件で あるとし、建物としては、冷熱削減効果 $139,616 \mathrm{MJ} /$ 年、温 熱削減効果は $90,844 \mathrm{MJ} /$ 年となる。

VAV制御による電力削減効果は、表 4(iii) 式より、冷房・暖 房負荷率からファンのインバータ周波数を算出し、これをイン バータ出力 $100 \%$ 時の電力量との差がVAV制御による削減 効果とする。AHUの給気ファン及び還気ファンの最小周波数を それぞれ $40 \% 、 70 \%$ とする。た本試算では、消費電力比は 冷房・暖房負荷率の 2 乗に比例するとし、よって削減電力比 $\lambda$ は、( 1 - 消費電力比)となる。図 8 より、1フロア一当たりの年間 削减電力量は $11 ， 975 \mathrm{kWh} /$ 年・階となった。よって、建物当 たりの年間削減電力量は $107,778 \mathrm{kWh} /$ 年となる。

熱源搬送ポンプインバータ制御による電力削減効果は、表 4 (iv) 式よりポンプ負荷率からポンプのインバータ周波数を算出 し、これをインバータ出力 $100 \%$ 時の電力量との差が本制御に よる削減効果とする。一次ボンプ、二次ポンプのの最小周波数 をそれぞれ $40 \% 、 40 \%$ とする。また消費電力比は、ポンプ負 荷率の 2 乗に比例するとし、削減電力比 $\lambda$ は、( 1 - 消費電力 比）となる。図 9 より年間削減電力量は、 $8,550 \mathrm{kWh} /$ 年とな る。

最後に、最適起動制御による省エネルギー効果の算定を行 なう。最適起動制御無し前倒し時間 $\mathrm{Hm}$ は、建物毎の運用によ るため設定值を表 10 に示す。またAHUの給気ファン及び還気 ファン動力はそれぞれ $2.2 \mathrm{~kW} 、 1.5 \mathrm{~kW}$ とする。表 $4(\mathrm{v})$ 式よ り、1フロアー当たりの年間削減電力量は、 $496 \mathrm{kWh} /$ 年・階と なった。よって、建物当たりの年間削减電力量は $4,464 \mathrm{kWh} /$ 年となる。

以上より、空調システムの経済的価值及び自動制御システム による省エネルギー効果について算定した。結果を表 11 にまと める。よって、年間の空調システムの正常運転確保の価值及び 省エネルギー効果の和は、4，401，422円／年となる。

\section{3 自動制御システムの機能維持の経済的評価}

2節より、自動制御システムの機能維持の経済価值は、自動 制御システムの性能劣化による空調システムの正常運転確保の 価值及び省ェネルギ一効果損头の回避額と捉えられる。

よって、(5) 式、(6)式より、第6.2節で算出した空調システム

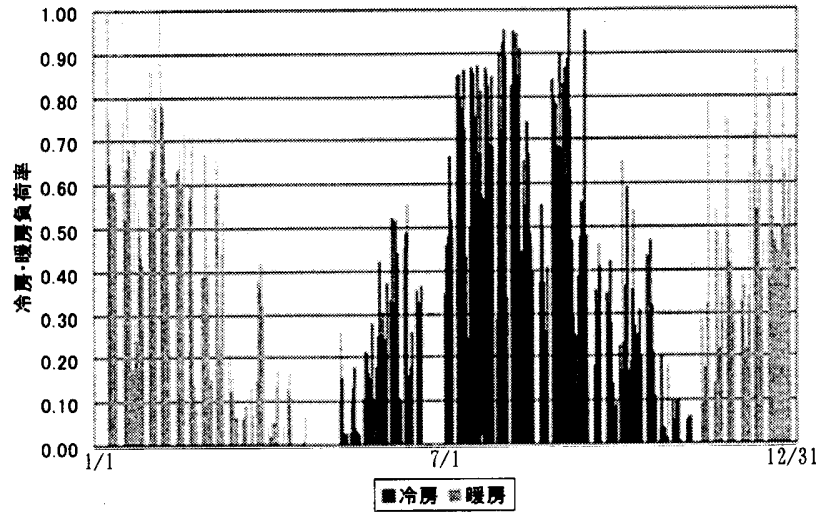

图 8 時刻別冷房・䁔房負荷率（2００２２年）

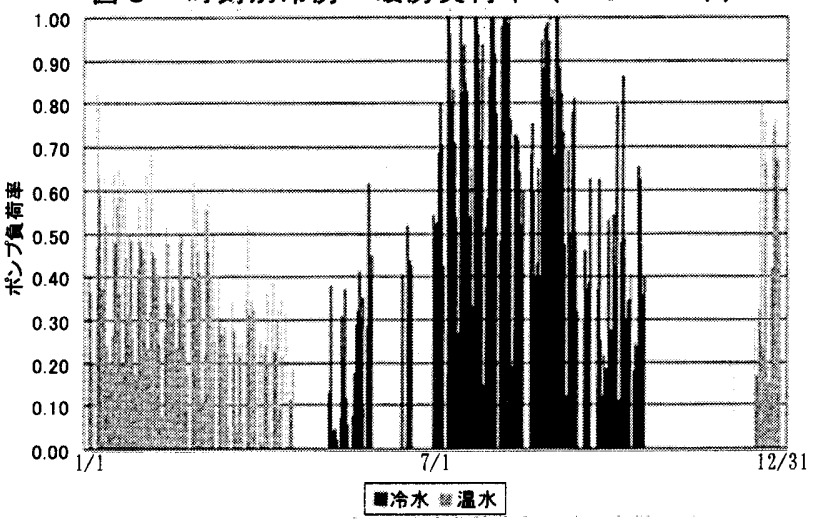

図 9 時刻別ポンプ負荷率（2002 年）

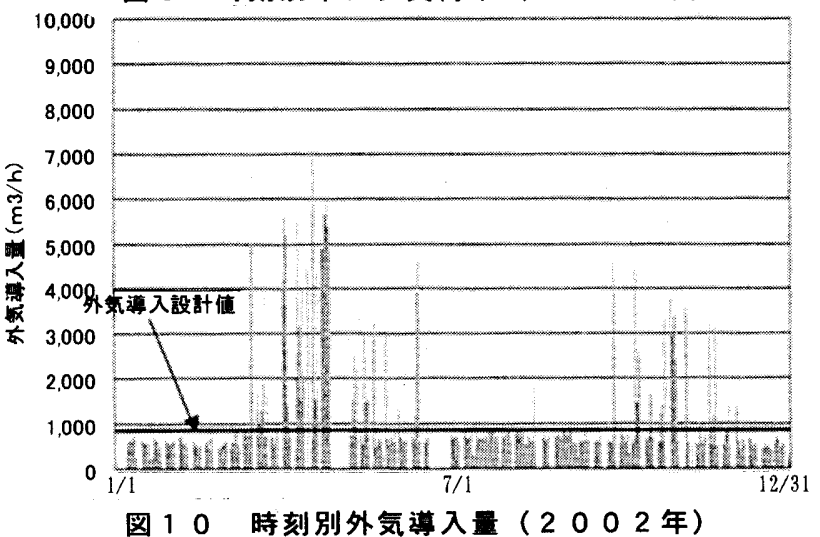

表 8 単価設定

表 9 室内環境萴定

\begin{tabular}{|c|c|c|c|c|}
\hline 五且 & 15 & 页 目 & \multicolumn{2}{|c|}{ 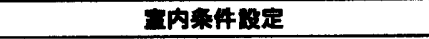 } \\
\hline$\frac{\text { 零力 }}{40}$ & $12 \mathrm{M} / \mathrm{kWh}$ & 冷房期 & 温度 $26^{\circ} \mathrm{C}$ 湿度 $50 \% \mathrm{RH}$ & $(52.88 \mathrm{~kJ} / \mathrm{kg})$ \\
\hline 温整 & $0.74 \mathrm{~g} / \mathrm{MJ} *$ & 中間期 & 温度 $24^{\circ} \mathrm{C}$ 湿度 $50 \% \mathrm{RH}$ & $(47.77 \mathrm{~kJ} / \mathrm{kg})$ \\
\hline *空㬐 & $\begin{array}{l}\text { COP(冷: } \\
\text {-り拏出 }\end{array}$ & 設計外気墨 & $321.41 \mathrm{~m}^{2} \times 3 \mathrm{CMH} / \mathrm{m}$ & $964.23 \mathrm{CMH}$ \\
\hline
\end{tabular}

表 10 最適起動制御時間設定

\begin{tabular}{|c|c|c|c|c|c|c|c|c|c|c|c|c|c|c|}
\hline \multicolumn{2}{|c|}{ 而目 } & \multicolumn{6}{|c|}{\begin{tabular}{|l|l|l|l|l|l|} 
& & \\
1
\end{tabular}} & & \multirow{2}{*}{ A } \\
\hline 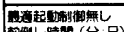 & $\mathrm{Hm}$ & 45 & ${ }_{45}$ & 30 & 30 & 30 & 60 & 80 & 60 & 60 & 30 & 30 & 45 & \\
\hline 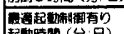 & $\mathrm{Hn}$ & 40 & 25 & 25 & of & 15 & 40 & 60 & 60 & 40 & 10 & 0 & 25 & 34 \\
\hline 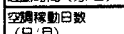 & D & 19 & 20 & 22 & 20 & 21 & 22 & 21 & 23 & 20 & 21 & 20 & 21 & 25 \\
\hline 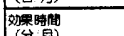 & $(H m-H n) \times D$ & 95 & 400 & 110 & 600 & 315 & 440 & 0 & 0 & 400 & 420 & 600 & 420 & 3,800 \\
\hline
\end{tabular}

の正常運転確保の価值をV 1 、省エネルギー効果をV2とし、稼 働 $\mathrm{n}$ 年目における自動制御システムの性能劣化率をPc $(\mathrm{n})$ とす ると、稼働 $\mathrm{n}$ 年目における自動制御システムの機能維持による 経済価値 MV $(\mathrm{n})$ は以下の式より算出される。

$$
M V(n)=\left(V_{1}+V_{2}\right) \times P c(n) \quad \cdots(7)
$$


毎年の自動制御システムの機能維持による経済価值 M N は、空調システム全体の想定稼働期間の件価として計上でき る。

$$
M N(k)=\frac{\sum_{j=1}^{k} M V(j)}{k} \cdots(8)
$$

$\mathrm{k}$ : 空調システムの想定稼働期間 (年)

本ケーススタディの場合、空調システムの稼働期間をそれぞ れ 1 年から 20 年と想定した場合の午間当たりの自動制御システ ム機能維持の経済価值を図 11 に示す。通常の空腺システムの 場合、システムの利用期間は、20 年前後と考えられ、以下に法 定耐用年. 数までの期間 15 午間とした場合 198 円 $/$ 午・ $\mathrm{m}^{2}$ 、更 新推定期間である 20 年間とした場合 349 円 $/$ 年・解となる。

\section{7. まとめ}

本研究を以下のようにまとめる。

(1) はじめに自動制御システムの機能維持の経済性評価に ついての基本的考え方を示した。そこで、機能維持の経済的価 值は、快適空誠システムの正常運転確保の価値と省エネル ギー効果の経済価值の低下を回避する行為と等価である定義 し、自動制御システムの機能維持の経済性評価の算出概念を 示した。

(2) 自動制御機器の故障履歴より、各機器の不信頼度及 び、保全サービスマンからのヒアリング調查を通して、機器故障 の影響度を調查した。また 17 棟の事務所ビルの自動制御機器 の故障履歴より各機器の不信頼度を算出した。この結果、影響 度及び不信頼度より各機能の経午による信頼度算出手法を示 し、システム性能劣化率を時刻礼に执ける機能維持を行わなかっ た場合のシステム中に存在する機能の累積不具合数の割合と 定義し算出式を示した

(3) 快適空調システムの正常運転確保の経済価値として、仮 想市場評価法により、事務所ビルの利用者に対し、空調が停 止しないための空凨サービス保険八の支払額を菏查した。その 結果、78.93円 $/ \mathrm{m}^{2}$ の值が得られた。また省エネルギー機能 による経済性評価として、外気冷房制御、C O 2 制御、V A V 制 御、熱源搬送ボンブインバー夕制御、最適起動停止制御の自 動制御システムによる省エネルギ一效果在提案した。

(4) 最後に、モデルビルのターススタディを通じて自動制御 システムの機能維持の経済性評価を行った。その結果、機能維 持の経済価值は、システム稼働想定期間を 15 午とした場合、1 93 円/午 $\mathrm{m}^{2}$ となり、図1の機能維持在適時行なった場合の費用 136 円 $/$ 午・ $\mathrm{m}^{2}$ より若干高めの值となった。

以上より本研究は、機能維持という費用対効果が見えない行 為に対して、経済的価値を算出する一手法を示したと言える。 のように、機能維持の経済的価值を示寸ことは、保全行為の促 進に慗がり、良質な建物を社全資本として蓄積させていくため には、重要であると考える。

また、今回調查で収集した故障データは、機器種の偏りもあ り、システム全体の性能劣化を示せるだけのデータ量ではなく、 全ての機器種類の不信頼度の算出には至ってはいない。また
表 11 空調システムの正常運転確保の価値 及び省エネルギー効果の算出

\begin{tabular}{|c|c|c|c|c|c|c|}
\hline 田 & w108 & 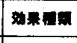 & I*k* & An & min & It \\
\hline \multirow{6}{*}{ 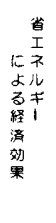 } & 苁気治房制街 & A A & $2.233 \mathrm{~m} / \mathrm{m} \cdot \mathrm{m}$ & $20,095 \mathrm{~m}$ & $18,607 \mathrm{~A} / \mathrm{q}$ & \multirow{6}{*}{$1,646.067 / /$ 年 } \\
\hline & \multirow{2}{*}{ CO2制徨 } & 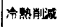 & $13,280 \mathrm{M} /$ q $^{2} \cdot \mathrm{m}$ & $119,521 \mathrm{Min} \cdot \mathrm{m}$ & $110,669 \mathrm{~m} / \mathrm{q}$ & \\
\hline & & 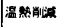 & 10.094 mate & 90,844 w:4 & $67,293 \mathrm{~F} / \mathrm{s}$ & \\
\hline & VAV制鹤 & 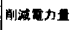 & $11,975 \mathrm{~mm} / \mathrm{s} \cdot \mathrm{m}$ & $107.778 \mathrm{~km} / \mathrm{a}$ & $1,293,336 \mathrm{M} /$ I $^{\prime}$ & \\
\hline & 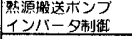 & 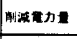 & \multicolumn{2}{|c|}{$8,550 \mathrm{~km} / \mathrm{m} / \mathrm{m} \cdot \mathrm{m}$} & $102,595 \mathrm{~m} / 4 / 4$ & \\
\hline & 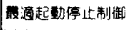 & 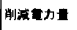 & 496 kMmin & 4,464 & $53,568 \mathrm{~m} / \mathrm{q}^{\mathrm{q}}$ & \\
\hline \multicolumn{6}{|c|}{ 空調システムのの正常運維確保の牺值 } & $2,755,355$ 丹 $/$ 年 \\
\hline
\end{tabular}

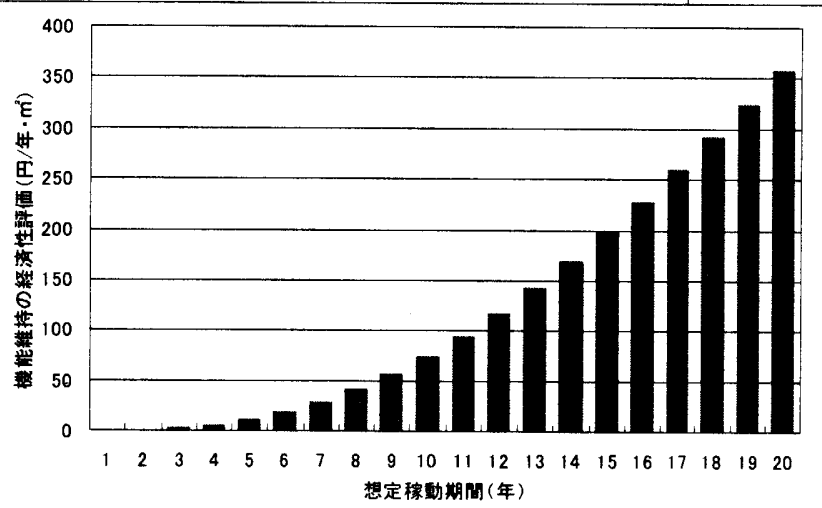

図 11 自動制御システムの機能維持の経済評価

影響度に関しても、ヒアリング人数に限りがあり、統計データとし ての信頉性が低いものと考える。今後は、これらのデータを月 常的に収集することにより、中唇期的な故障の予測、効率的な メンテナンス計画などに生かせる基礎的デー夕を構筑する必要 があると考える

\section{参考文献}

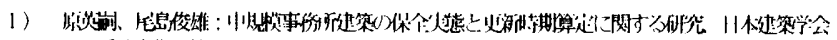

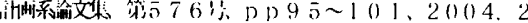

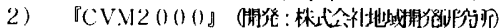

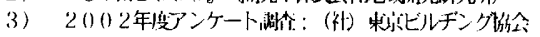

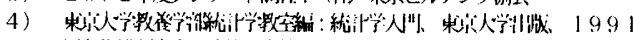

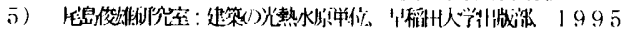

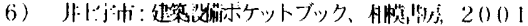

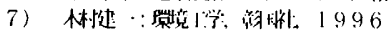

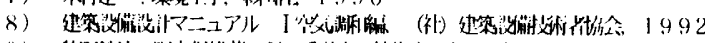

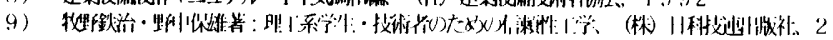
000

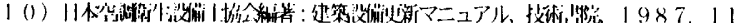

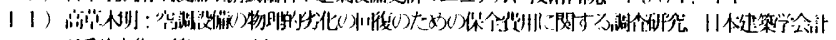

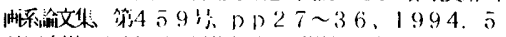

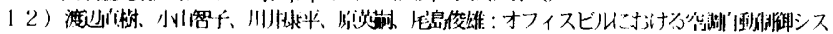

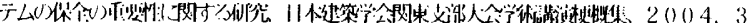

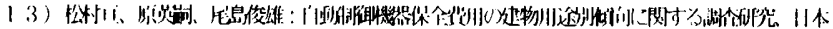

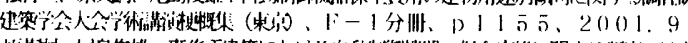

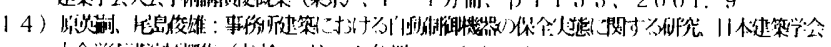

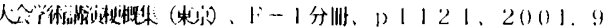

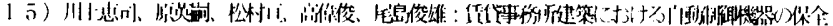

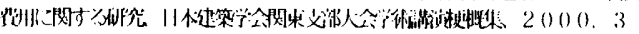

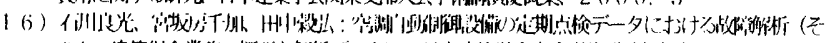

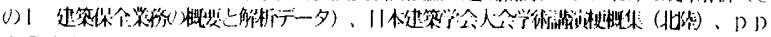
$1541 \sim 1542,1992.8$

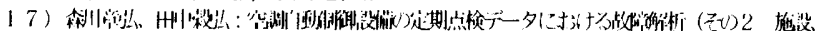

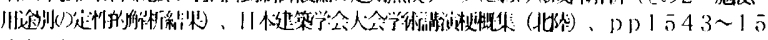
44. 1992.8

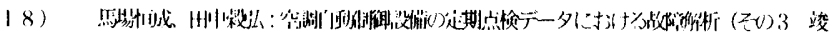

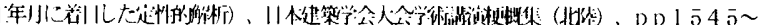
$1546,1992.8$

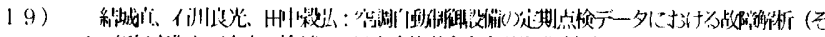

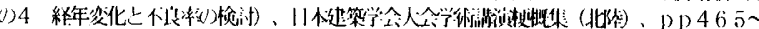
$466,1993.9$

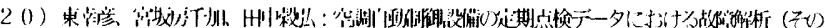

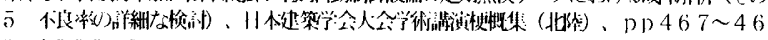
8. 1993.9

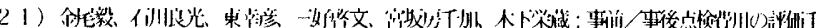

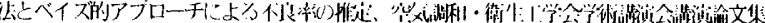

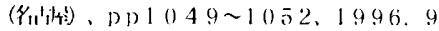

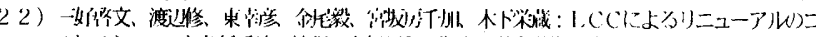

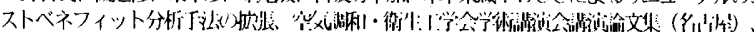
pp8.3.3 836, 1996.9 